\title{
In Vitro Perfusion of the Human Utero-tubo-ovarian Unit
}

I. Experimental Conditioning and Perfusion of the Unit with Normal Pregnancy or Trophoblastic Neoplasia

\section{Shimpei TOJO, Matsuto MOGHIZUKI, Seiichi KANAZAWA, Toshiyuki SHIMURA, Katsunobu MIKAMI Toshiaki TSUGHIHASHI and Hidenobu FUKUNISHI}

Department of Obstetrics and Gynecology Kobe University School of Medicine (Director : Prof. S. Tojo)

Using a newly modified machine for organ preservation, the authors made an in vitro perfusion study of the human utero-tubo-ovarian unit concerning the pregnant uterus or the uteri including trophoblastic neoplasias.

During perfusion, they measured serially and continuously $\mathrm{PO}_{2}, \mathrm{PCO}_{2}, \mathrm{pH}, \mathrm{Ht}$, erythrocyte count, pyruvate, lactate, hGG, hPL and progesterone in the perfusate and detected also the uterine electric depolarization with electromyography.

At the same time, the authors used radioautography to know the DNA- and RNAsynthesizing activity of the endometrium and normal or neoplastic trophoblastic tissues which were obtained with divided biopsies during perfusion.

Testing these parameters for viability and function of organs, the authors succeeded to preserve the human utero-tubo-ovarian unit including normal or neoplastic trophoblastic tissue in vitro.

Namely, active polypeptide hormones (hCG and hPL)-release from the trophoblastic tissues in various conditions was recognized and nucleic acid synthesizing activity was also certified through the whole course of the perfusion.

From these experimental results, the authors might reasonably conclude that, with this in vitro organ perfusion experiment, they could preserve the normal or neoplastic trophoblastic tissue which was included in the human utero-tubo-ovarian unit.

(See pp. 1103 1118) 


\section{ヒト「子宮卵管卵巣ユニット」の In vitro 灌流実験}

I 。潅流条件の検討と初期妊娠ならびに絨毛性腫瘍に関する知見

神戸大学医学部産科婦人科学教室
東 條 伸 平, 望 月 真 人
金 沢 精 一, 三 上
志 椦 信
福 西 秀 信

（昭和48年 4 月 4 日受付）

新らしく改良した臟器灌流装置につき灌流条件の詳細な検討を行つたのち，正常初期妊娠あるいは絨 毛性腫痬を含む「子宮卵管卵栄ユニット」の in vitro 灌流実験を試み，乙れらの絨毛組織細胞が全経 過にわたり旺盛な RNA 合成を行つているととを推論し，また絨毛性 polypeptide hormones のうち 特に hCG の放出が活発に行われているととを認めることができた，なお， RNA 合成や hCG の放出 は actinomycin-D 投与により明瞭に阻止された.

緒 言

著者らは「子宮卵管卵巣ユニット：utero-tubo-ovarian unit」の in vitroにおける灌流実験により，臟器

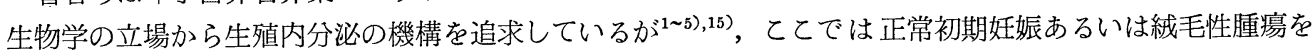
もつとのユニットの内分泌機能を中心にして, 実験条件の設定の仕方や生活現象のパラメーターを検討した 成績を報告する.

\section{1. 実 験 方 法}

\section{A. 灌流装置について}

著者らが開発した第 1 号機の藏器灌流保存装置の詳細はすでに発表してある ${ }^{13)}$. 現在, 著者らはての 1 号機を改良した第 2 号機を使用しているが，機構上 1 号機と異なるとてろを列記すると下記のようになる.

i. 人工心は air compressor に直結した電磁弁の制御によつて駆動されるベロフラム型のポンプであり, 弁は Ball 弁によに逆流を防ぐため空洞弁としてある.

ii. 動脈圧波形の補正としての compliance 機構を空気圧としてある.

iii. 静脈系の灌流液にはそのリターンの問題を考虑して落差と陰圧を加え, 直接人工肺に送りてまれる.

iv. 人工肺は 8 枚の disk からなり，空気栓塞を防ぐために灌流液の貯槽を新たに人工肺内に設置した。

v. 臓器に入る灌流液がたえず $37^{\circ} \mathrm{C} に$ 加温されているようにするために, 熱交換器を特に蔵器の in put 側にもおき, 熱調節器をての熱交換器内に設置した.

vi. 動脈圧, 心搏数と搏出量を正確に知るためにシンクロスコープを設置し, 拍出量とリズムを実験材料 によつて適当に変えることができるようにした.

\section{B. 灌流液と酸素化}

細胞におけるガス交換能，血管抵抗，血栓形成及び浸透圧の変化を考虑し，5000 iu heparin, 5000 iu 
Fig. 1. Schematic presentation of the whole machine for organ perfusion.

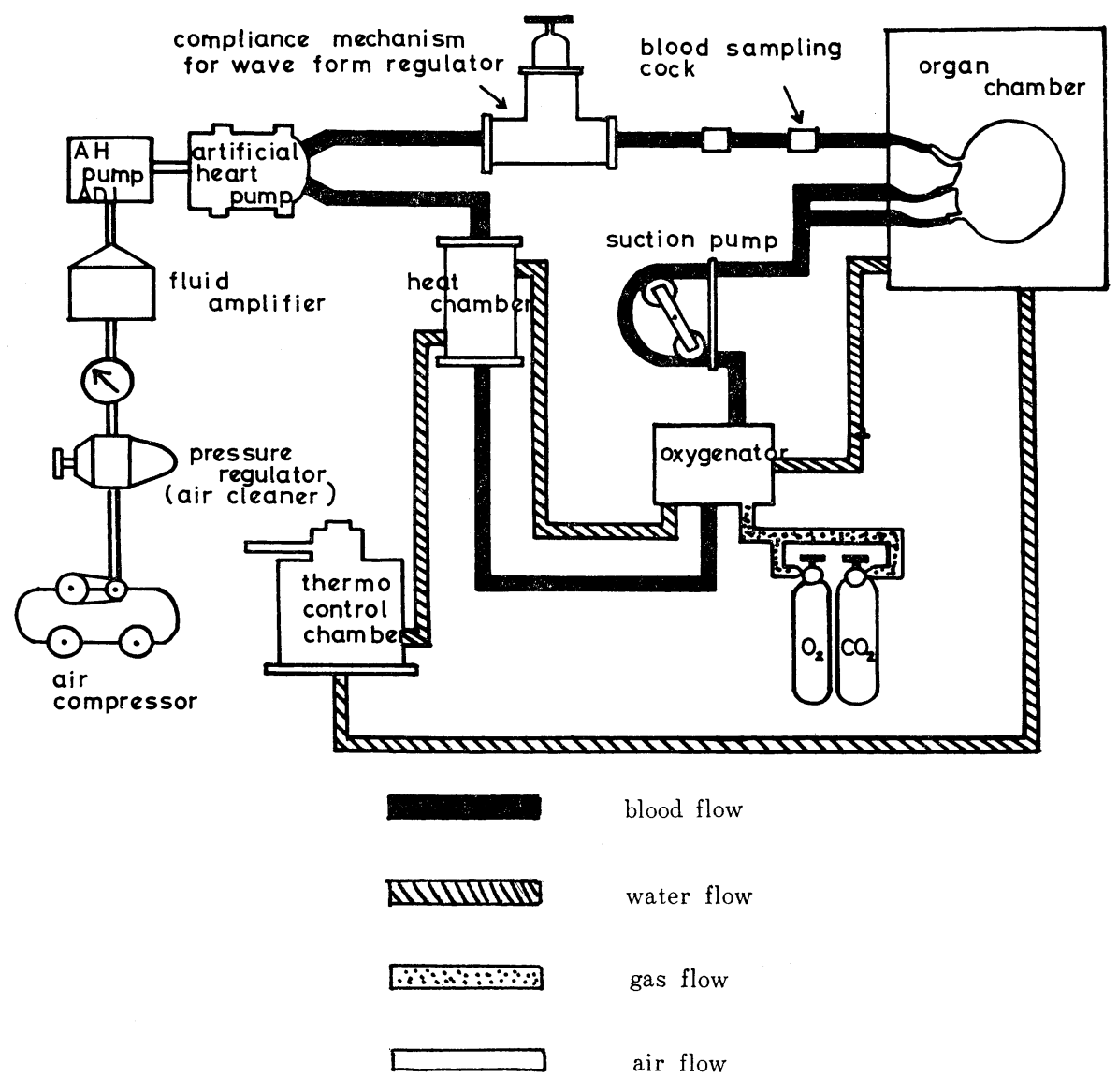

urokinase を加えた $6 \%$ dextran-10\% Hanks 液で20\%の稀釈血液を作り， pH 7.40 に調節したものを灌 流液として使用した，灌流液総量は $400 \mathrm{ml}$ である.

酸素化装置に使用するガスは，酸素 $95 \%$ ，炭酸ガス $5 \%$ の混合ガスであり，灌流中の液の $\mathrm{pO}_{2}, \mathrm{pCO}_{2}$, $\mathrm{pH}$ などの変化に応じ，供給量やその混合比を調節し，特に $\mathrm{pH}$ の変化は sodium bicarbonate ならびに 炭酸ガス供給量の変換によつて調節した (Fig. 1).

\section{C 材 料}

実験に用いた材料は，筋腫子宮，巨大筋腫を合併した妊娠子宮あるいは絨毛性腫瘍子宮で，両側あるいは 片側の卵巣，卵管を含めて，つまり「utero-tubo-ovarian unit」として摘出したものを用いた。

子宮の摘出にあたり，特に灌流装置への連絡を出来るだけ容易に，すばやく出来るように子宮動静脈なら びに卵巣静脈を含む lig. infundibulo-pelvicum を子宮側に出来るだけ長く残して切断した.

\section{D. 子宮一卵管一卵巣ユニットと装置との連結}

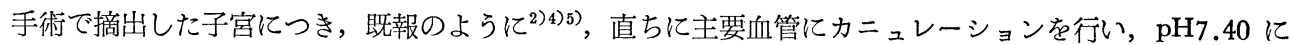
調節した低分子デキストラン，ブドウ糖，硫酸マグネシウム及びヘパリンを含む電解質溶液で子宮血管を洗 涤し，すでに必要条件のもとに作動している装置の動脈系に a. uterina をまた静脈系にv. uterina plexus pampiniformis 内にある v. ovarica をそれぞれ連結する (Fig. 2). 
Fig. 2. Diagram of in vitro perfusion of the human utero-tubo-ovarian unit.

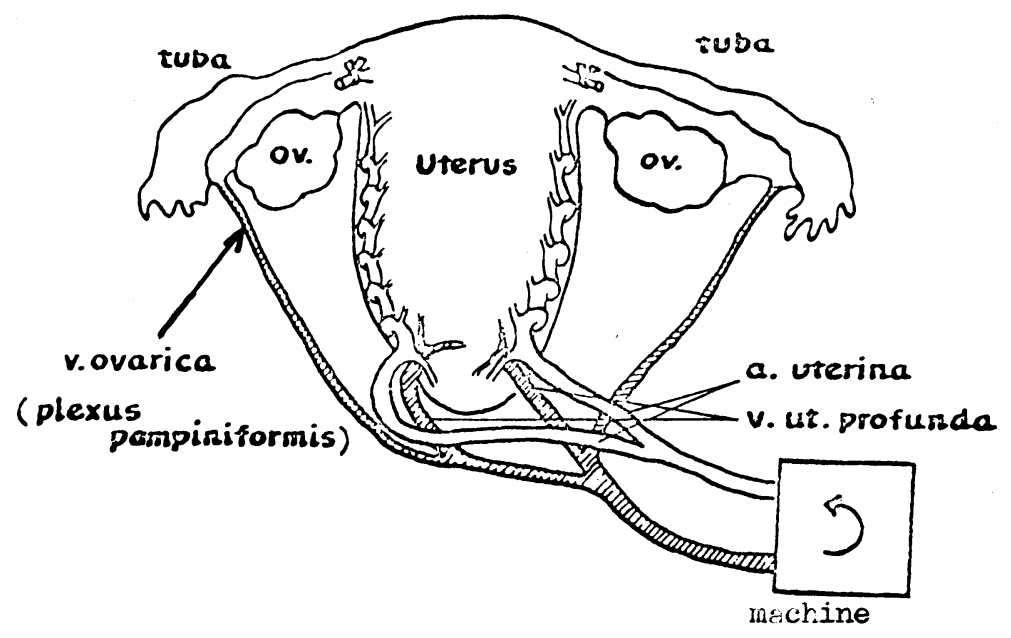

\section{E. 生活現象のパラメーター}

この種の実験における灌流藏器の生死を判定するととは, きわめて困難な問題であるとともに特に重要な ことでもある.

現在, われわれはパラメーターとして以下のものを採用している.

i. 灌流中の子宮の action potential の連続的検出.

ii 灌流液の組成や生化学物質の変化を知るために, 赤血球数 (RBC), $\mathrm{Ht}, \mathrm{pO}_{2}, \mathrm{pCO}_{2}, \mathrm{pH}$, pyruvate, lactate, lactate/pyruvate ratio (L/P ratio), LDH などの連続的測定.

iii。絨毛性腫煌子宮あるいは娃娠筋腫子宮では hGG, hPL と progesterone 量の連続的測定.

iv。筋腫子宮ではその内膜につき, また䋐毛性腫瘍子宮, あるいは妊娠子宮では, その絨毛組織について 灌流時定期的に biopsy を行い，その組織片につき， ${ }^{3} \mathrm{H}$-thymidine, ${ }^{3} \mathrm{H}$-uridine の取込みを flash labeling による radioautograph で検討する.

F パラメーターの測定法

上述したパラメーターの測定は以下の方法で行つた。

i. 筋電図は双心針電極を用いて筋電図增幅器を介し, 多用途記録装置により記録した。電極針の刺入部 位は，子宮では子宮卵管角部筋首，卵管では卵管壁笳首，卵巣では門部わよび卵胞あるいは黄体の近接部位 である.

ii. 赤血球数は, トーマ血球計算器, $\mathrm{Ht}$ は毛細管法を用い, $\mathrm{pO}_{2}, \mathrm{pCO}_{2}, \mathrm{pH}$ は Astrup 装置 ${ }^{14)}$ につて 測定した。

iii. pyruvate, lactate $は \mathrm{HClO}_{3}$ で脱蛋白し, NADH 吸収法を利用した柴田の方法で測定した ${ }^{6) \tau}$.

iv. LDH は INT 法を用いた中外製薬製のユニキットにより測定した ${ }^{8)}$.

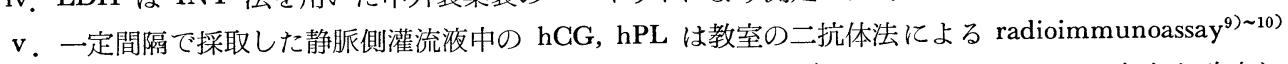
により，また progesterone は competitive protein binding assay ${ }^{11)}$ にる，Johanson の方法を改良し て用いた。

vi. radioautograph の作製には biopsy により取り出した小組織切片を用い，てれを ${ }^{3} \mathrm{H}$-thymidine あ るいは ${ }^{3} \mathrm{H}$-uridine $10 \mu \mathrm{ci} / \mathrm{ml}$ を含む medium 199 を注入した試験管内に入れて $37^{\circ} \mathrm{C}, 2$ 時間 incubation した後 medium 199 で 2 回洗涤し, ホルマリンで固定, 乳剤はサクラNR-M により radioautograph を作製, 対照染色には $\mathrm{H}-\mathrm{E}$ 染色を用いた ${ }^{12)}$. 


\section{II. 実 験 成 績}

\section{A. 装置のコントロールに関して}

装置のコントロールに関する基礎的検討成績は以下のでとくである.

i. 流量と stroke

これは pump が 1 号機と同じベロフラム型往復 pump であるため，第 1 号機に順じた ${ }^{13)}$.

ii. 酸素化

disk の回転数とガス流量の関係を Fig. 3 亿示す. $\mathrm{pO}_{2}$ は disk の回転数が 6rpm. ではその上昇が急で あり,また $350 \mathrm{ml} / \mathrm{min}$ の gas flow の例では hyperoxemia となつた以後, 急に $\mathrm{pO}_{2}$ が低下している. 回転数 $2.5 \mathrm{rpm}$., gas flow $70 \mathrm{ml} / \mathrm{min}$ でも充分酸素化ができている.

iii. 赤血球 $(\mathrm{RBC})$ ならびに $\mathrm{Ht}$ の変化

Fig. 4 にみられるように灌流液中の $\mathrm{RBC}$ は空洞弁圧が $2.0 \mathrm{~kg} / \mathrm{cm}^{2}$ 以上では急激に減少したが $1.5 \mathrm{~kg} /$ $\mathrm{cm}^{2}$ では緩除であつた，Ht の変化も RBC の推移と一致した。

iv. 動脈圧波形

空気圧による compliance 機構での動脈圧波形は Fig. 5 のでとくであり，1 号機の場合133) と同様生体内 での子宮動脈圧波形に類似させるととができた。

Fig. 3. $\mathrm{pO}_{2}$ in the perfusate following oxygenation with different gas flow.
A : on $6 \mathrm{rpm}$. of the disk

$\mathrm{B}$ : on 2.5rpm. of the disk

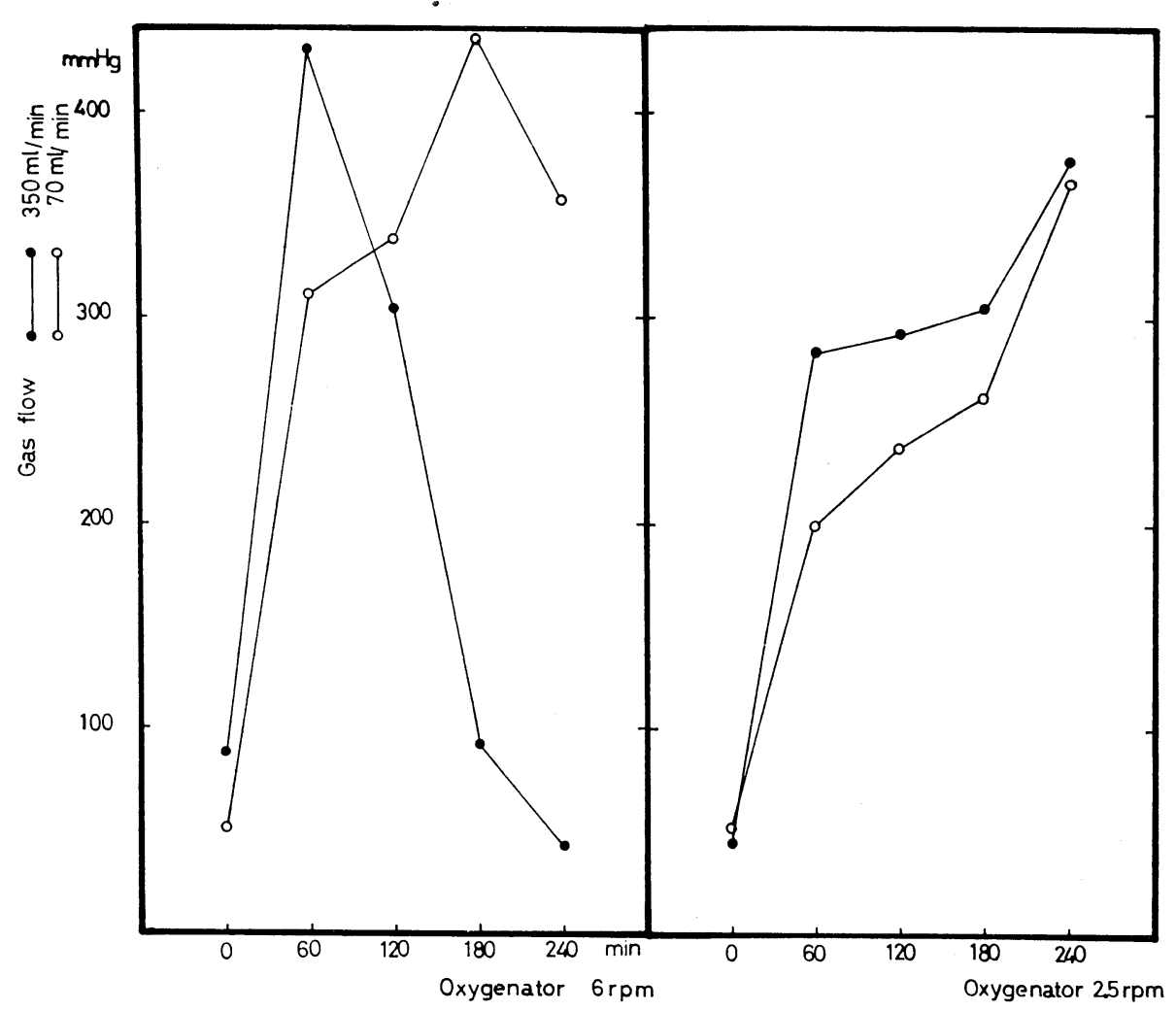

第 49 巻 第 8 号 
Fig. 4. Ghanges of erythrocyte count (RBC) hematocrit $(\mathrm{Ht})$ on the different pressure to tube valve. $\mathrm{RBC}$ and $\mathrm{Ht}$ are not changed on the pressure of $1.5 \mathrm{~kg} / \mathrm{cm}^{2}$ to tube valve.
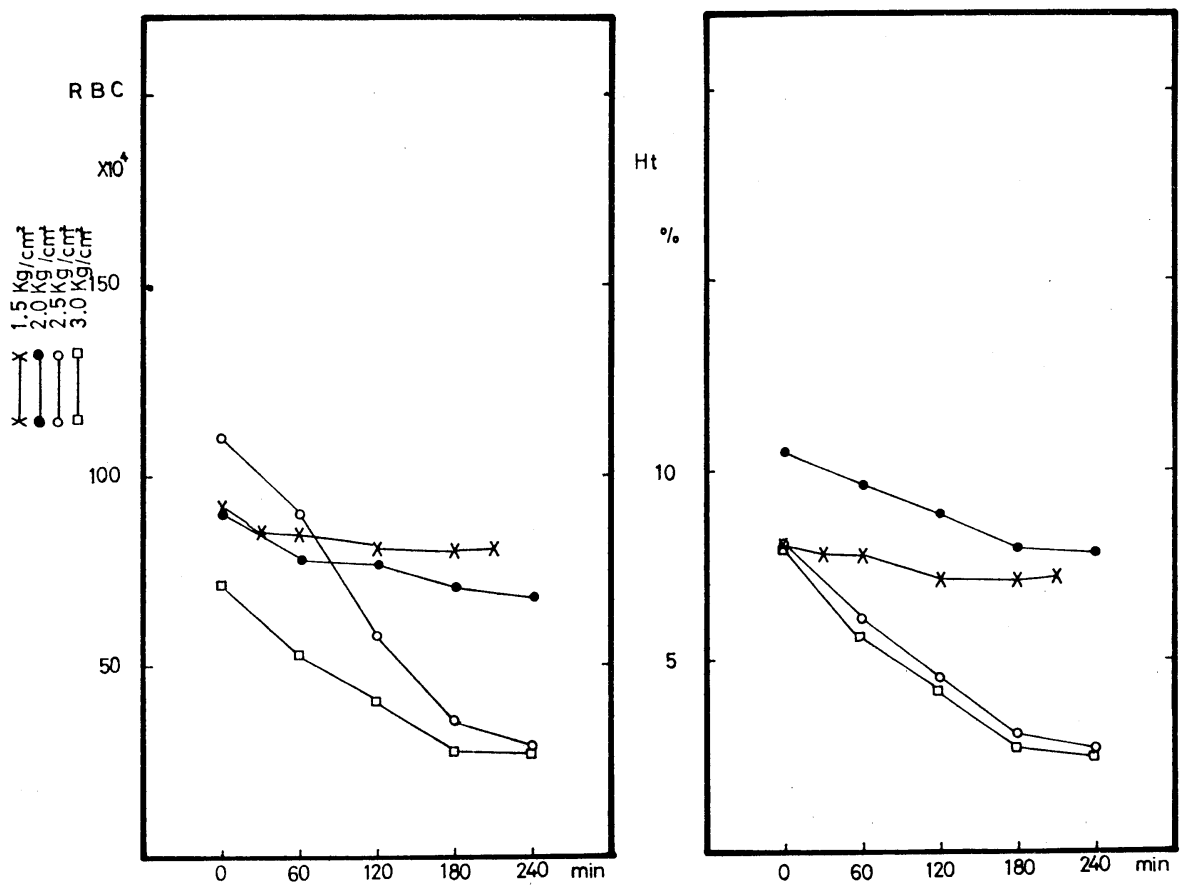

Fig. 5. Comparison of the wave forms between uterine artery in vivo and the machine.

A : wave forms at the various parts of the original compliance mechanism

$\mathrm{B}$ : changes of wave forms in the renewed compliance mechanism at the pressure to amplifier $\mathrm{PS}=0.9 \mathrm{~kg} / \mathrm{cm} .^{2}$

$\mathrm{a}$ : by tightness of air $(1.0 \mathrm{~cm}) \quad \mathrm{b}:$ by tightness of air $(2.0 \mathrm{~cm}) \quad \mathrm{c}:$ by tightness of air $(3.0 \mathrm{~cm})$

A

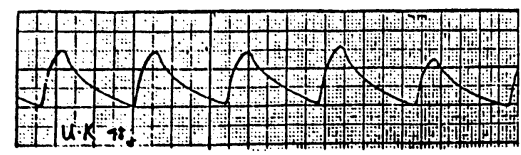

wave form of the uterine artery

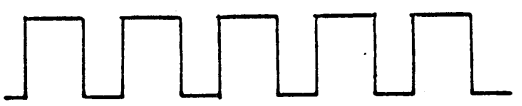

wave form at the outlet of artificial heart pump

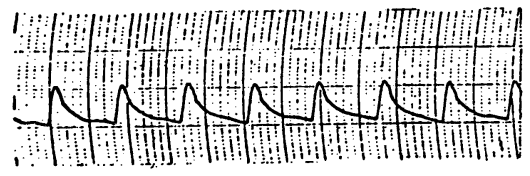

wave form at the outlet of wave form regulator
B
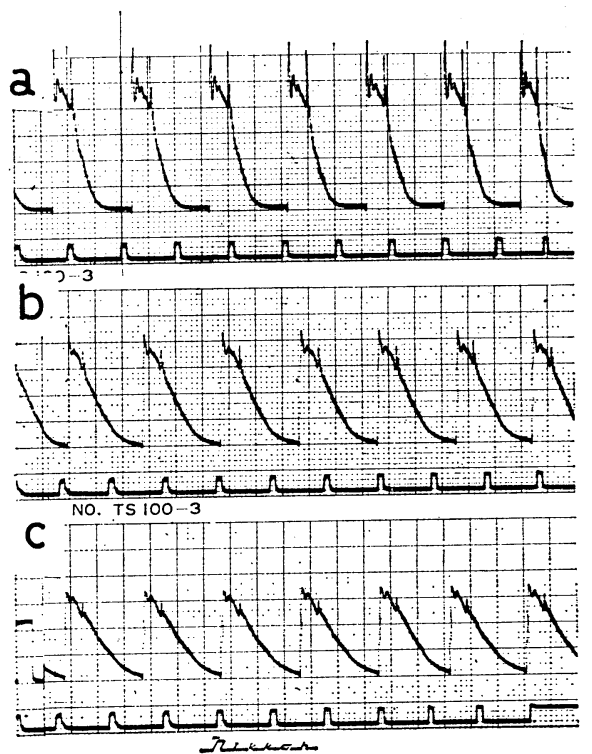

第 49 巻 第 8 号 


\section{v。本装置による灌流のための基本条件}

以上の成績から，「子宮卵管畉巣ユニット」の灌流には stroke の長さ $4 \mathrm{~mm}$ ，ポンプ 拍動数 $60 \mathrm{c} / \mathrm{min}$, disk の回転数 $2.5 \mathrm{rpm}$., gas flow $70 \mathrm{ml} / \mathrm{min}$, 空洞弁圧 $1.5 \mathrm{~kg} / \mathrm{cm}^{2}$, ポンプ駆動圧 $0.9 \mathrm{~kg} / \mathrm{cm}^{2}$ の基本条件とし た。 ての場合灌流中における灌流液の $\mathrm{pO}_{2}, \mathrm{pCO}_{2}, \mathrm{pH}$ を control するためにてれらを Astrup 法によつ て連続的に測定しその都度 disk の回転数と gas flow の量を変えた.

\section{B. 灌流時における各パラメーターの変化}

筋腫子宮の成績を例にとり，灌流実験成功例と不成功例に分け，各パラメーターの変化を対比すると，以 下のようになる。

i. 成功例について

a, $\mathrm{pO}_{2}, \mathrm{pCO}_{2}, \mathrm{pH}$. の変化について

Fig. 6 は灌流開始後210分までの動脈側 $\mathrm{pO}_{2}, \mathrm{pCO}_{2}$ 及び $\mathrm{pH}$ の変化を示している. $\mathrm{pO}_{2}$ は灌流開始と共 に速やかに上昇しているが，灌流開始後 30 分で急下降している．Astrup 法により上記諸因子の変化を検討 しながら disk の回転数を $4 \rightarrow 6 \rightarrow 8 \rightarrow 12 \mathrm{rpm}$. と変え, gas flow も $70 \rightarrow 125 \rightarrow 200 \rightarrow 275 \mathrm{ml} / \mathrm{min}$ と変えてコ ントロールしたとてろ，ほぼ好条件に安定した。

静脈側における $\mathrm{pO}_{2}, \mathrm{pCO}_{2}$ および $\mathrm{pH}$ の変化を Fig. 6 に示す. 動脈側で $\mathrm{pO}_{2}$ の急激な下降が見られ た時期に静脈側では反対に $\mathrm{pCO}_{2}$ の上昇が見られたが，以後ほぼ安定した推移を示している.

b. pyruvate, lactate, lactate/pyruvate ratio (L/P ratio) と LDH そついて

Fig. 6. Changes of $\mathrm{pO}_{2}, \mathrm{pCO}_{2}$ and $\mathrm{pH}$ in the perfusate during the perfusion of myometous uterus with various gas flow and rpm. of oxygenator.

A : inlet part of the organ chamber

B : outlet part of the organ chamber

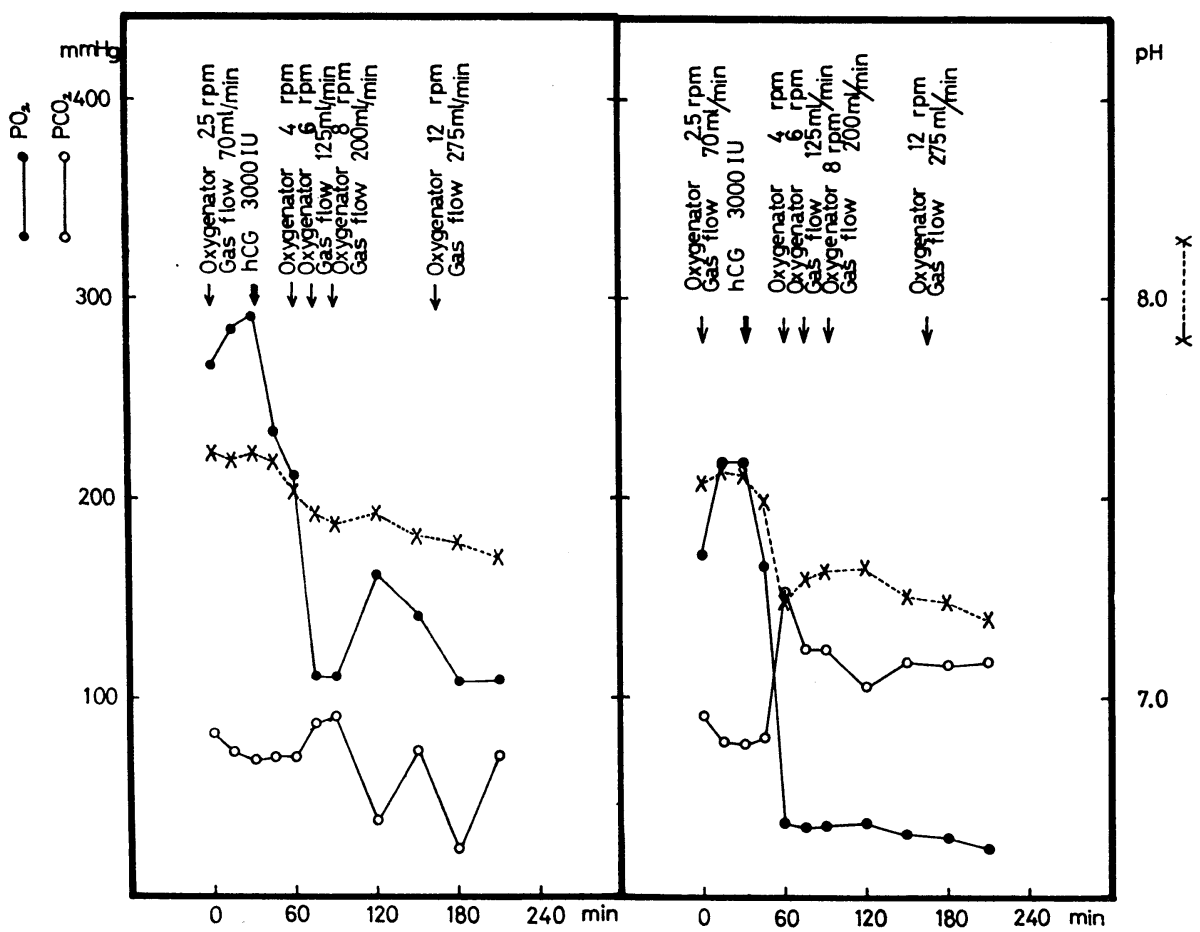


Fig. 7. Lactate, pyruvate, their ratio and $\mathrm{LDH}$ of the perfusate (successful case).

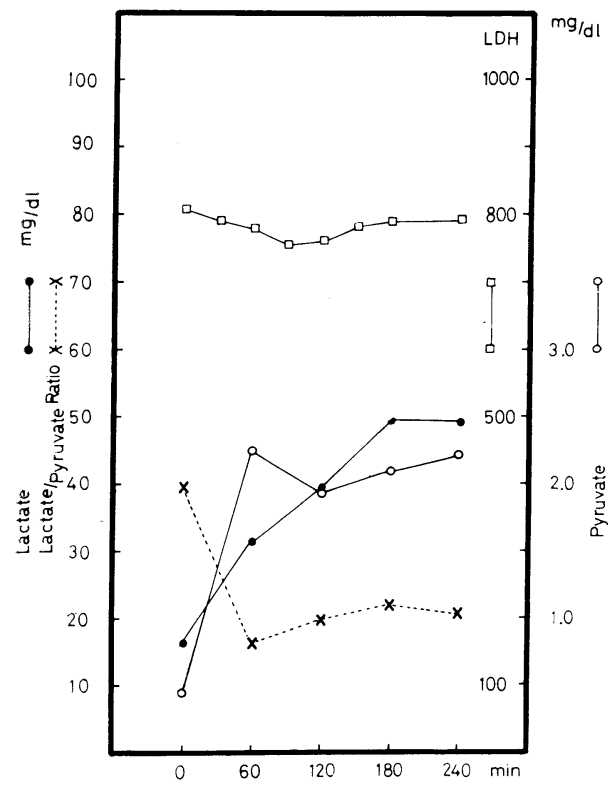

Fig. 8. The uterine electromyogram during perfusion

A : after $60 \mathrm{~min}$. perfusion

B : after $120 \mathrm{~min}$. perfusion

G : after $180 \mathrm{~min}$. perfusion

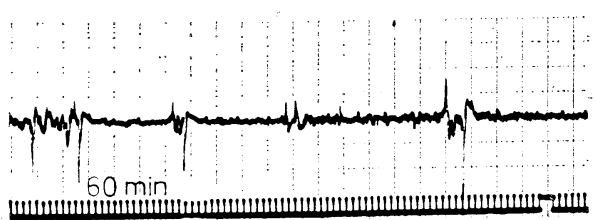

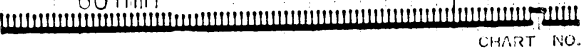

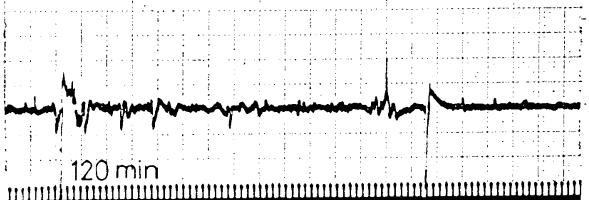

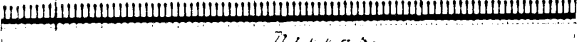

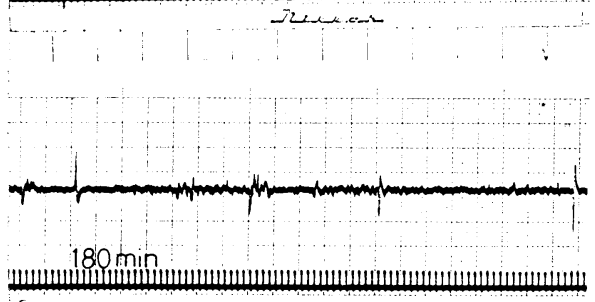

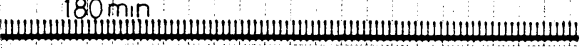

Fig. 9. Radioautograph of the endometrium (midproliferative phase).

A : ${ }^{3} \mathrm{H}$-thymidine uptake of the endometrium after $60 \mathrm{~min}$. perfusion

$\mathrm{B}:{ }^{3} \mathrm{H}$-uridine uptake of the endometrium after $60 \mathrm{~min}$. perfusion

A

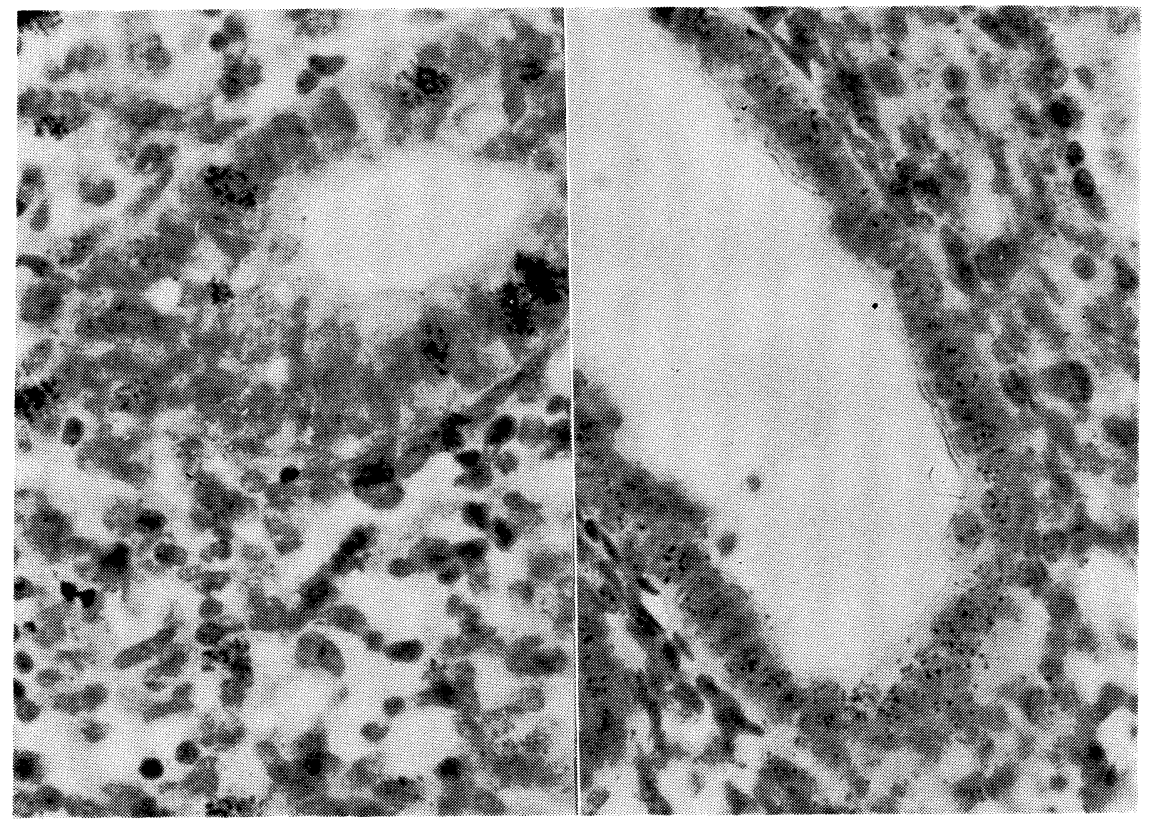

第 49 巻 第 8 号 
灌流開始後30分以後では lactate はりるやかに増加する傾向を示したが pyruvate は著明な変化を示さず, 60分以後の L/P ratio は安定している (Fig. 7)。また LDH の動きにも著変はない。

C. 筋電図について

Fig. 8 は灌流開始後 60 分，120分，180分後の子宮筋電図である. 子宮筋の action potential が活ぼ規則正 しく現われており，しかもこの所見は灌流終了時まで認められた。

d. radioautograph について

灌流開始後の子宮内膜で Fig. 9 亿示すでとく ${ }^{3} \mathrm{H}$-thymidine, ${ }^{3} \mathrm{H}$-uridine の取込みが認められた。

ii。不成功例について

a. $\mathrm{pO}_{2}, \mathrm{pCO}_{2}$ と $\mathrm{pH}$ の変化について

酸素化は，灌流開始後経時的に下降し， $\mathrm{pCO}_{2}$ は上昇， $\mathrm{pH}$ の下降が見られる。

b. Lactate, pyruvate, lactate/pyruvate ratio $\varepsilon$ LDH について

Lactate 量の急速な増加とともに pyruvate の下降が認められ，また $\mathrm{L} / \mathrm{P}$ ratio の急激な上昇が見られる (Fig. 10)。 LDH も L/P ratio と類似した動きを示している.

C. 筋電目について

子宮筋の action potential は灌流開始当初わずかに梽められたが，まもなく認められなくなつた。

d. radioautograph について

灌流開始後 60 分ですでに子宮内膜上皮細胞，腺細胞の ${ }^{3} \mathrm{H}$-thymidine の取込みは認められていない。

\section{C、緁毛性腫崵子宮の灌流実験成績}

i.コントロール実験における hCG と hPL の動態

まず䋐毛性腫瘍子宮の灌流を行う前にコントロール実験として筋腫子宮を灌流し，灌流液中に hCG を溶 解し，経時的にサンプリングして hCG の推移を追求することと，筋腫子宮の筋㜿内に，hCG，hPL を注 入したあと，経時的にサンプリング，灌流液中に放出される hGG, hPL を測定するととを試みたが Fig. 11 に示すごとく hCG, hPL ともに投与後60分以内でその值は peak となり，その後は減少傾向を示した.

Fig. 10. Changes of $\mathrm{pO}_{2}, \mathrm{pCO}_{2}, \mathrm{pH}$, lactate, pyruvate, L/P-ratio and $\mathrm{LDH}$ in the perfusate (failed case).
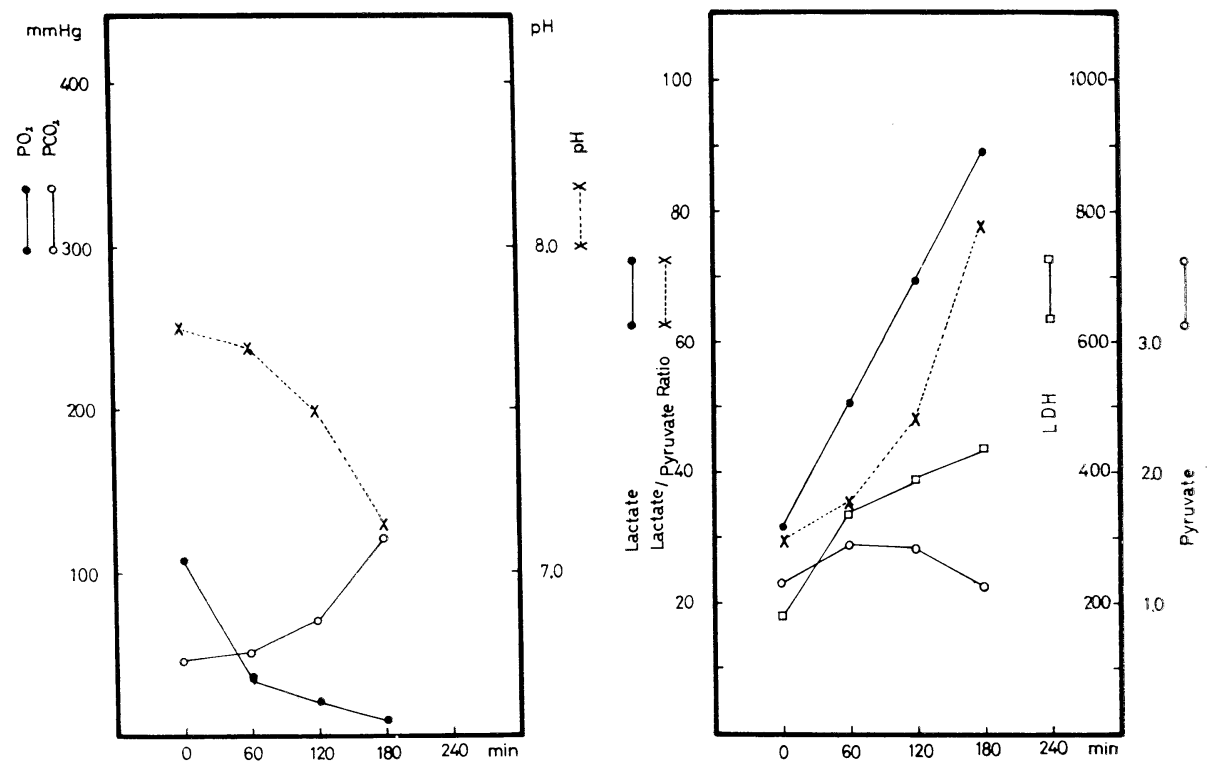

第 49 巻 第 8 号 
Fig. 11. HCG and hPL during perfusion of myomatous uteri.

A : perfusate contains exogenous hCG

$\mathrm{B}$ : exogenous hCG and hPL were injected into the uterine muscular layer

A

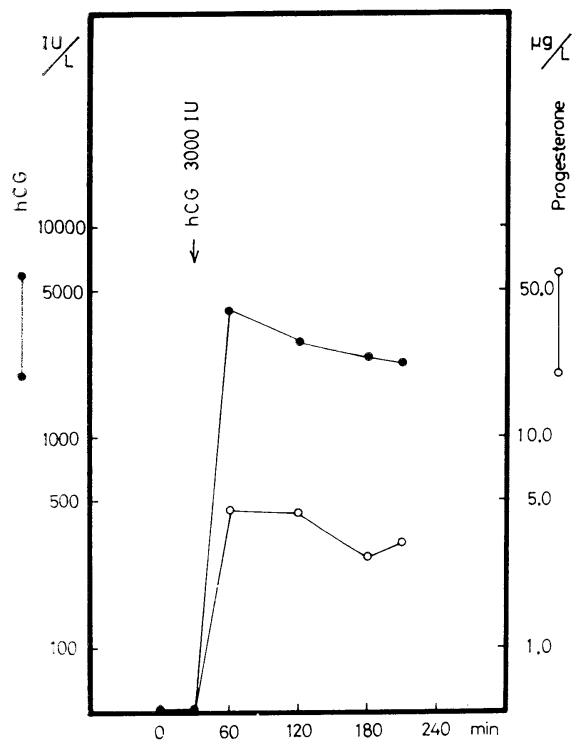

B

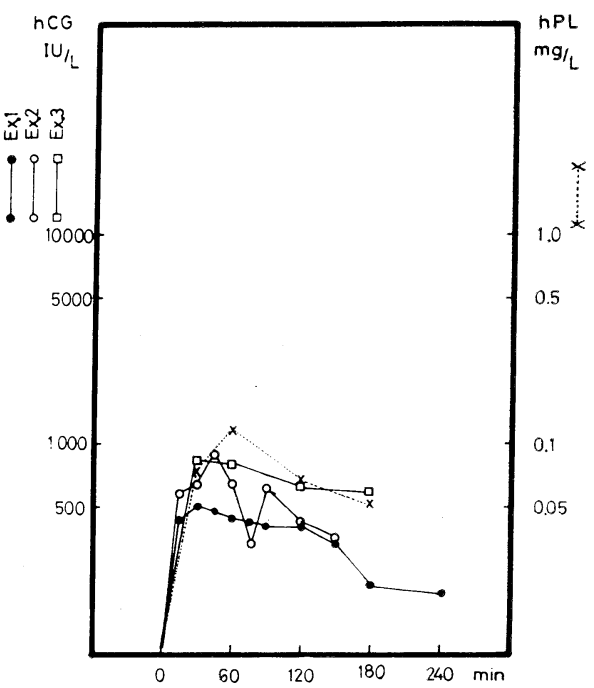

Fig. 12. HCG and hPL during perfusion of the utero-tubo-ovarian unit with trophoblastic neoplasia (succeeded cases).

Ex. 1 chorioadenoma destruens

Ex. 2 chorioadenoma destruens

Ex. 3 hydatidiform mole

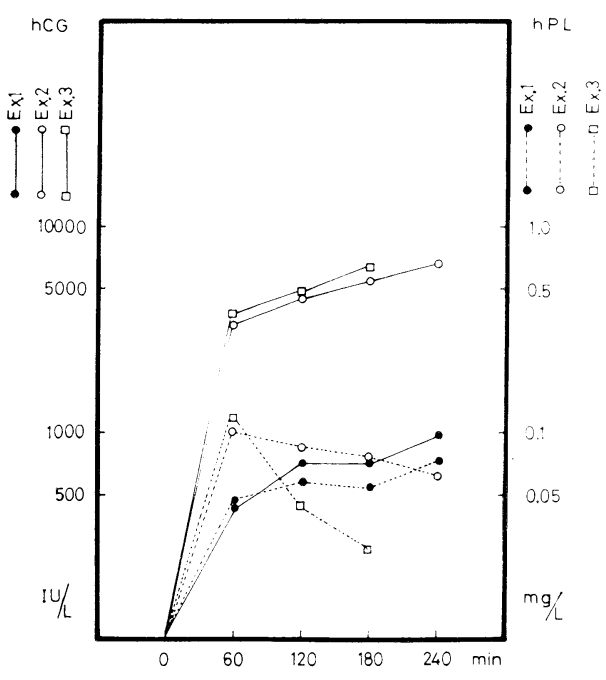


ii。䋘毛性腫演子宮の灌流実験における hCG と hPL の動態

a 。成功例における灌流液中の hCG と hPL

radioimmunoassayにより測定した hCG と hPL 量の動態を Fig. 12 に示す. hCG は先述のコントロー ル実験におけるパターンと異なり，経時的に増加している。

Fig. 13. ${ }^{3} \mathrm{H}$-thymidine uptake of neoplastic trophoblast masses during perfusion A : after $60 \mathrm{~min}$. perfusion

B : after $180 \mathrm{~min}$. perfusion

C : after 240min. perfusion (Case. Ex. 2, see Fig. 12.)

A

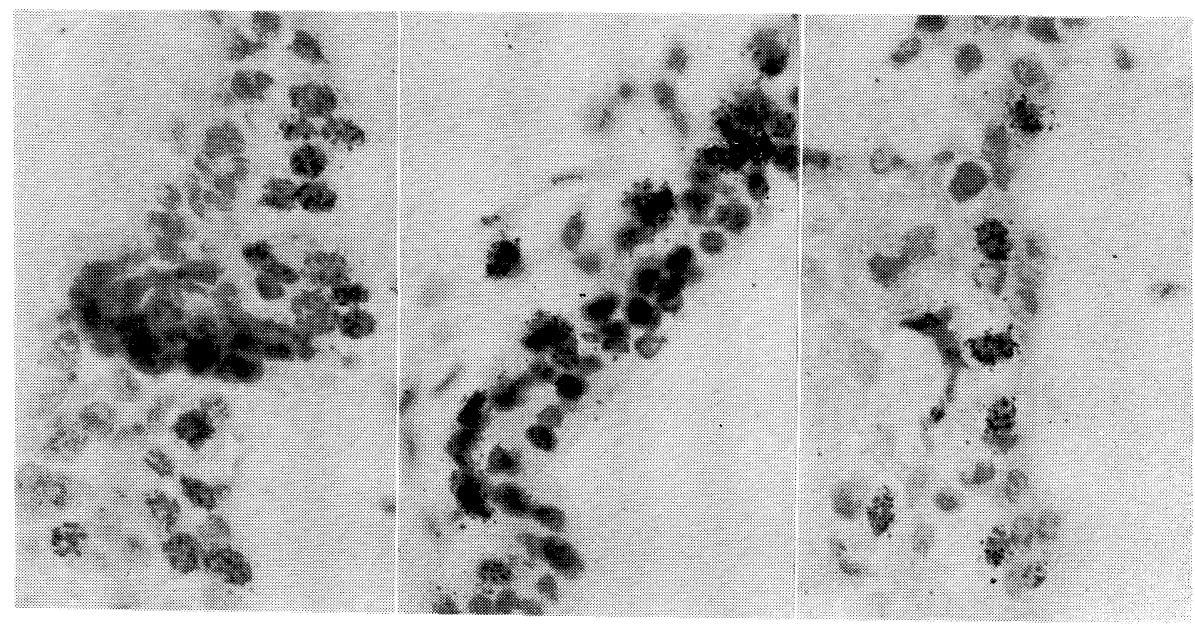

Fig. 14. ${ }^{3} \mathrm{H}$-thymidine uptake, ${ }^{3} \mathrm{H}$-uridine uptake of neoplastic trophoblast masses during perfusion.

A : ${ }^{3} \mathrm{H}$-thymidine radioautograph after $180 \mathrm{~min}$ perfusion

B : ${ }^{3} \mathrm{H}$-uridine radioautograph after $180 \mathrm{~min}$. perfusion

(Case. Ex. 3, see Fig. 12)

A

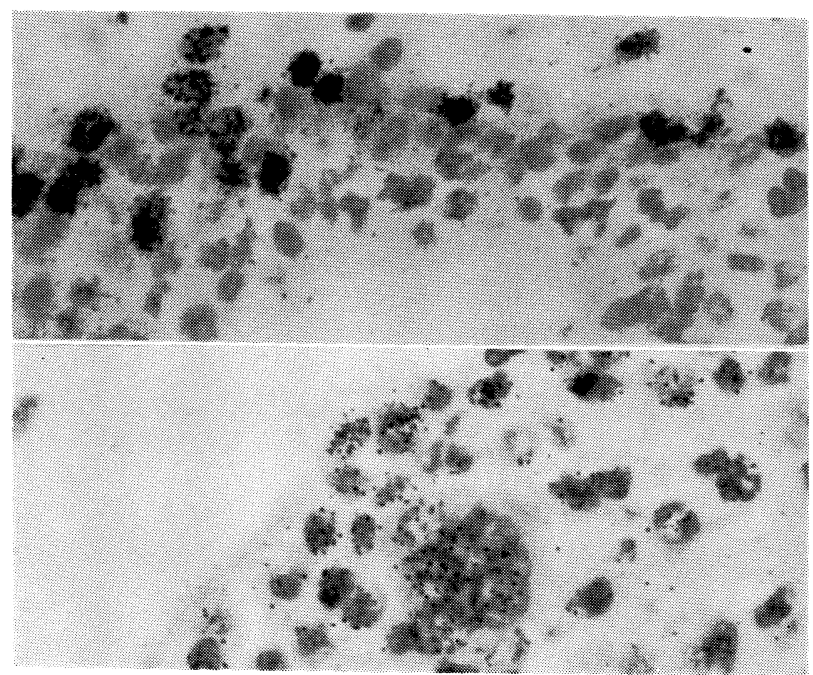

第 49 巻 第 8 号 
Fig. 15. HCG and hPL in the perfusate with trophoblastic neoplasia (failed case).

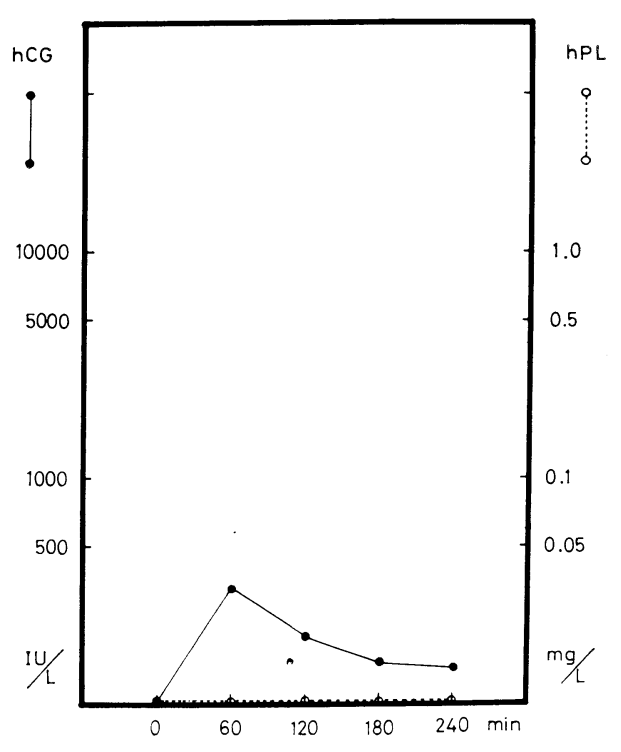

Fig. 16. Perfusion of a case of the utero-tuboovarian unit with chorioadenoma destruens (treated with actinomycin-D during perfusion).

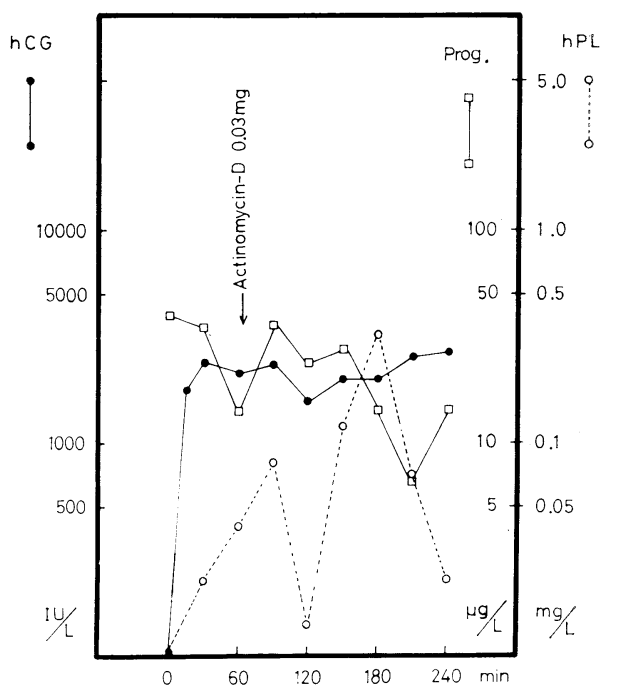

Fig. 17. ${ }^{3} \mathrm{H}$-thymidine uptake of neoplastic trophoblast masses during perfusion. (a case of chorioadenoma destruens)

A : before the administration of actinomycin-D.

B : $60 \mathrm{~min}$. after the administration of actinomycin-D.

C : $120 \mathrm{~min}$. after the administration of actinomycin-D.

$\mathrm{D}: 180 \mathrm{~min}$. after the administration of actinomycin-D.

A

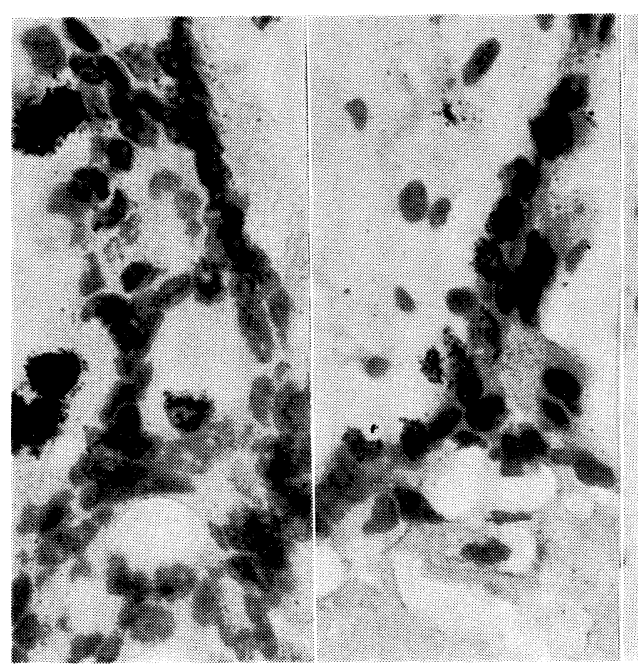

$\mathrm{C}$

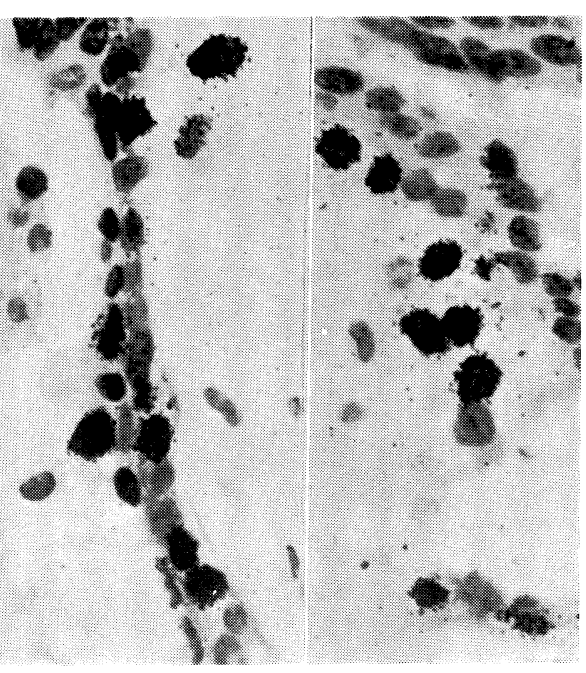


hPL のパターンは不定である。

てれらのケースの灌流中における各パラメーターは筋腫子宮の成功例におけるそれに類似していたまた， Ex. 2 で行つた経時的分割 biopsy による組織片の radioautograph は Fig. 13 のごとくであり，灌流終了 時まで ${ }^{3} \mathrm{H}$-thymidine の取込みを認める。また，Ex. 3 で得た灌流終了時の radioautograph を Fig. 14 に 示す. ${ }^{3} \mathrm{H}$-thymidine, ${ }^{3} \mathrm{H}$-uridine の活発な取込みが認められる。

b，不成功例における灌流液中の hCG と hPL

hCG と hPL 量の推移を Fig. 15 に示すが，hGG 量は成功例のそれとは異なり，むしろ前述のコントロ ール実験におけるパターンに類似して減少傾向を示し，hPL は測定不能であつた。

筋電図は灌流開始後まもなくキャッチ出来なくなつたし，灌流開始後180分後の腫癔組織の radioautograph では ${ }^{3} \mathrm{H}$-thymidine, ${ }^{3} \mathrm{H}$-uridine の取込みはほとんど認められなかつた.

lii. 絨毛性腫瘍子宮の灌流時における actinomycin D の影響

a. actinomycin D $0.03 \mathrm{mg}$ を 1 回のみ投与したケース.

actinomycin D 0.03mg（全灌流液量 $400 \mathrm{ml}$ ）を灌流開始60分後に注入し，各種バラメータ一の変化を検 傠した。

Fig. 18. ${ }^{3} \mathrm{H}$-uridine uptake of neoplastic trophoblast masses during perfusion.

(a case of chorioadenoma destruens)

A : before the administration of actinomycin-D.

B : 60 min. after the administration of actinomycin-D.

C : $120 \mathrm{~min}$. after the administration of actinomycin-D.

$\mathrm{D}: 180 \mathrm{~min}$. after the administration of actinomycin-D.

A

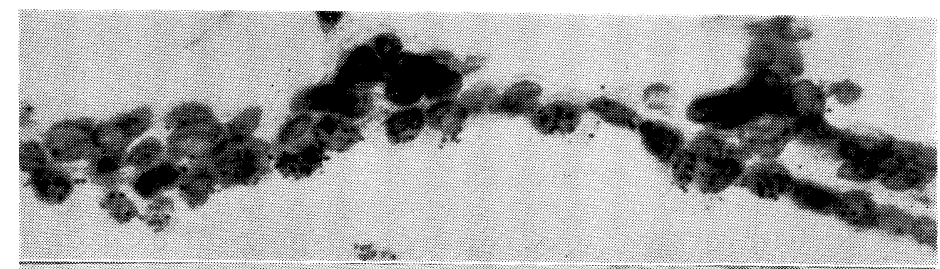

B

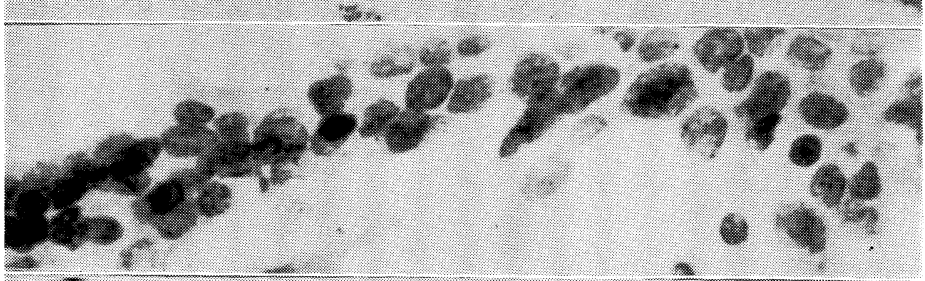

C

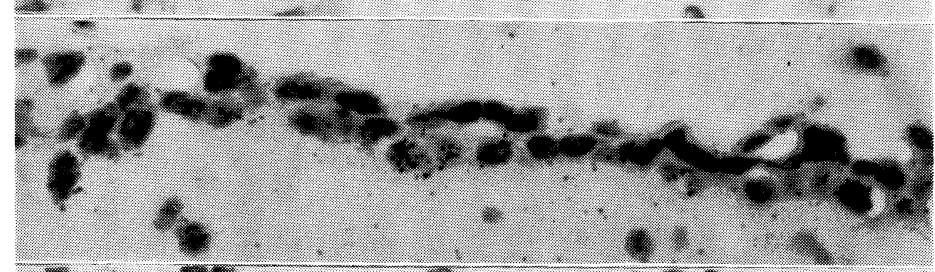

D

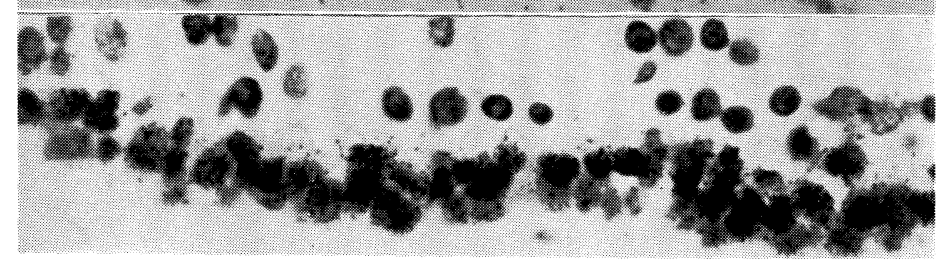

第 49 巻 第 8 号 
酸素化は灌流全期間中充分に行われ，L/P ratio も急増せず LDH もプラトーのパターンをたどり, 筋電 図も終始キャッチできたケースでの hCG, hPL および progesterone 量の経時的な推移を Fig. 16 亿示す. actinomycin D 注入後 hCG レベルはプラトーとなり, progesterone は漸減し, hPL のパターンは不定で ある.

この灌流実験時における腫瘍細胞の ${ }^{3} \mathrm{H}$-thymidine, ${ }^{3} \mathrm{H}$-uridine の取込みを Fig. 17, Fig. 18 亿示す。 actinomycin D 投与前での ${ }^{3} \mathrm{H}$-thymidine の取込みは核内に著明に珰められ, ${ }^{3} \mathrm{H}$-uridine のそれも著明で あるが, 投与 60 分後では特に ${ }^{3} \mathrm{H}$-uridine の取込みが著しく減少している. しかし投与120分後では回復の傾 向がみられる。

b. actinomycin D $0.03 \mathrm{mg} 2$ 回投与例

actinomycin D $0.03 \mathrm{mg}$ を灌流開始 30 分後に注入し, 更に 120 分後に $0.03 \mathrm{mg}$ を注入したケースの hCG 之 hPL 量の経時的な推移を Fig. 19 亿示す。初回投与後, hCG 值は減少傾向を示すが，投与60分後にや や増加し，第 2 回目の投与により hGG 值はプラトートなり hPL は減少した。

D. 初期妊娠子宮（妊娠 3 ケ月の筋腫子宮）灌流時における hCG, hPL および progesterone の動態 灌流全経過を通じて酸素化は十分行われ， lactate や L/P ratio の急上昇もなく，LDHもほぼプラトー の推移を示し, 筋電図も終始キャッチできた。灌流液中の hGG hPL および progesterone の測定成績を Fig. 20 に示す.

hCG, hPL ともに漸増傾向を示している. progesterone は経時的に減少した。灌流終了後の緁毛組織の radioautograph では ${ }^{3} \mathrm{H}$-thymidine, ${ }^{3} \mathrm{H}$-uridine の取込みが著明に認められた (Fig. 21)。

Fig. 19. Perfusion of a case of the utero-tuboovarian unit with chorioadenoma destruens. (treated with actinomycin-D during perfusion)

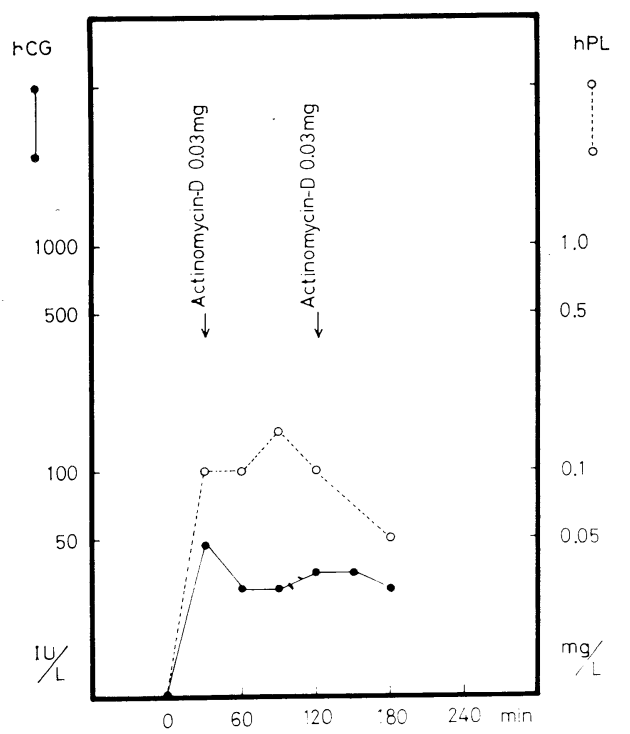

Fig. 20. Perfusion of the pregnant utero-tuboovarian unit with uterine myoma.

-O- - : hCG

$-\square-\square-$ : progesterone

$-\mathrm{O}-\mathrm{O}-: \mathrm{hPL}$

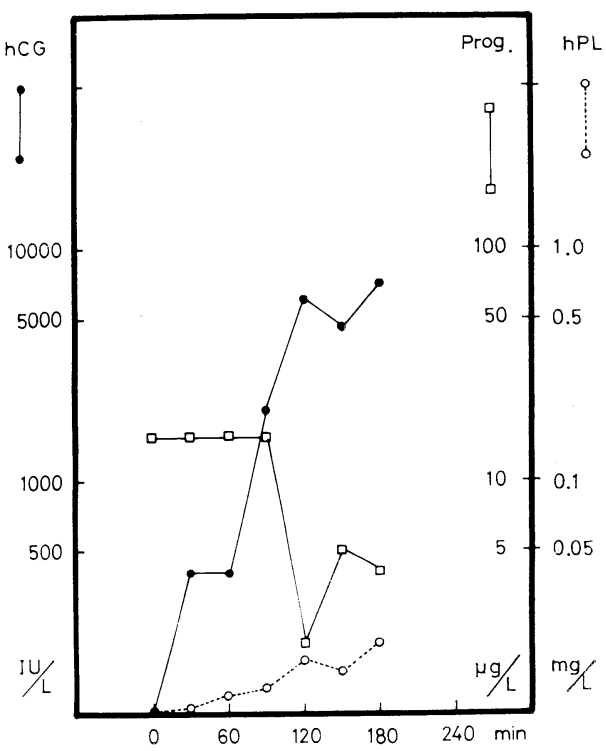


Fig. 21. ${ }^{3} \mathrm{H}$-thymidine and ${ }^{3} \mathrm{H}$-uridine uptake of normal trophoblast masses after $180 \mathrm{~min}$. perfusion.

A : ${ }^{3} \mathrm{H}$-thymidine radioautograph

B : ${ }^{3} \mathrm{H}$-uridine radioautograph

A

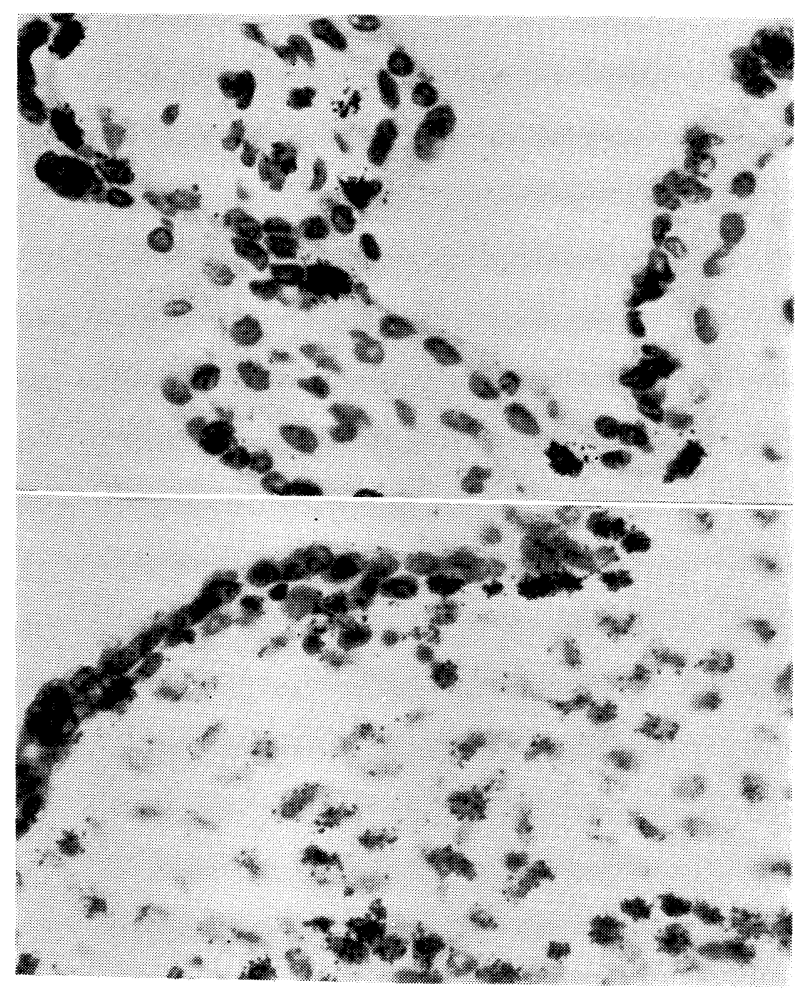

III. 考

按

この種の灌流実験で最も問題になるのは, いかにして蔵器の生体内条件を满足させるかということと, 灌 流時の臓器が機能を保持し得ているかというととの判断である。

一般に体外灌流時における蔵器の細胞の機能低下，あるいは死は灌流液および臓器の温度低下，血栓形成， 血管の戀縮や弛緩などの変化, 毛細血管抵抗性の増大, 生理的でない連続流やガス交換の不足, さらにはそ れらによつて引き起てされる㨀気性代謝の京進などが複雑に組み合わさつて成立するものと考えられる ${ }^{13}$.

このような原因を最少限に止めるために著者らは pulsing pump, 圧波補正装置，さらに高性能の酸素附 加装置や保温装置などに新らしい工夫を凝らした体外灌流装置を用いて「utero-tubo-ovarian unit」の灌流 実験を行つている。まだ満足すべき条件を完備することはできていないが特に灌流中の酸素化は重要であり， われわれは Astrup 装置で灌流液の $\mathrm{pO}_{2}, \mathrm{pCO}_{2}, \mathrm{pH}$ を連続的に測定しつつ, 必要に応じて disk の回転数 こ gas flow を変え, $\mathrm{pO}_{2}, \mathrm{pCO}_{2}, \mathrm{pH}$ をコントロールした.

いうまでもなく, この種の体外灌流実験で重要な問題は, 灌流時の臟器が果して機能を保持しているかど うかという点にあり, viability のパラメーターとしては, 従来より一般的に灌流液中の GOT や GPT 活 性, ブドウ糖および酸素消費能, 灌流液中の lactate, pyruvate, 尿素窒素および pH などが注目されてい る.

われわれの筋腫子宮での灌流実験でも, 実験不成办例では, lactate 量が著増したり, L $\mathrm{P}$ ratio が急上 
昇し，また LDH もとれと類似した傾向を示した.

これに反して成功例では, lactate, pyruvate はやや漸増の傾向は示すが急増するてとはなく，L/P ratio も低值もしくはプラトーのままに推移し，LDH パターンもてれに類似した。すすなわちてれらの所見はかな り充分な酸素消費を反映しているものと考えられる。

また，子宮の specific living parameter としての子宮筋電図をみると，成功例では灌流終了まで明瞭な 脱分極像が証明されているのに反して，不成功例では灌流開始後まもなく認められなくなる.

さて, 絨毛性腫瘍子宮あるいは初期妊娠子宮の実験における灌流液中の hCG と hPL の推移をみると, 筋腫子宮を灌流し，灌流液中に hGG を注入した際のそのホルモンの量的推移，さらには筋腫子宮の筋首内 に, hCG, hPL を注射しその後の灌流液中の hCG, hPL 動態をくらべたコントロール実験の成績に比較す ると, 全く異なつたパターンを示した。

つまり hGG 量は灌流開始と共に急上昇し，以後は漸次増加する傾向を示した。しかしながら，hPL は 不定なパターンをとつている. てのような hCG と hPL の動態の違いはての種の腫瘍において, hGG の 産生に比して hPL の分泌量が極めて少ないととと, さらには hPL の half life が極めて短かいととに由 来するものと思われる.

絾毛性腫瘍子宮の灌流中に actinomycin D 0.03mg を1 回投与したケースでは，灌流液中の hCG には 投与後 1 時間は増加傾向がみられず，むしろ逆に減少するが，その後再び増加した．また， 2 回投与のケー スでは hGG は一方的に低下傾向を示すのみであつた。

この際の腫疸細胞の DNA, RNA 合成に関する radioautograph の所見は hGG 量の推移と似ていた.

このような成績を actinomycin D 非投与群の灌流液中の hCG, hPL の動態や, 腫焬細胞の radioautograph の成績と比較すると, 灌流中に腫場細胞が積極的に DNA, RNA を合成する能力を確かに持ち続け ていたというとと，また腫瘍量と actinomycin D 投与量との関係にも影響されるにちがいないが, 一般に RNA 合成はこの灌流条件下でも actinomycin D によつて抑制されるが，てれも数時間のうちに回復する 傾向のあるととがわかる。

つまり, 紱毛性腫場子宮, 正常妊娠筋腫子宮の灌流実験においては, 灌流液中の hGG, hPL 量の推移と 共に定期的な biopsy によつて採取した腫煬細胞の ${ }^{3} \mathrm{H}$-thymidine, ${ }^{3} \mathrm{H}$-uridine の取込みの所見が腫瘍の機 能に関する有力なパラメーターとなると考えられ, 灌流成功例においては, 核酸合成と共に, 少なくも hGG は積極的に産生放出されているものと考朰られる。

\section{結 語}

われわれは既報の藏器灌流装置を用いて,「utero-tubo-ovarian unit」の灌流実験を行い, 最近, 得た成績 を述べてきた。

ての種の研究では, 藏器を生体内のコンディションに類似させるととの困難さと, 藏器自体の生活現象を 示すパラメーターの選び方が重要なポイントとなる.

適正なコンディションを設定するためには, メカニカルな問題と共に灌流液中の血球成分や $\mathrm{Ht}, \mathrm{pO}_{2}$ $\mathrm{pCO}_{2}$ あるいは $\mathrm{pH}$ の恒常化が重要な問題である.

Viability のパラメーターは子宮筋の笳電図を始め, 灌流液中の lactate, pyruvate 量, あるいは両者の 比 (L/P ratio), LDH さらには子宮内膜, 緁毛組織などの DNA 合成能が, また䄉毛性腫瘍子宮や正常妊 娠筋腫子宮の機能的パラメーターとしては, hGG, hPL ならびに progesterone などのホルモンの量の変化, および上記組織細胞関する RNA 合成能の検討なぎが有力な指標となるととがわかつた。

以上の如く，藏器の体外灌流法を完成させる事は容易なととではないが，著者らの試みている「uterotubo-ovarian unit」の in vitro perfution はヒト生殖生理学の分野に役立つものと考えている.

謝辞

本研究における潅流装置の開発に御助言と御協力いただいた早稻田大学理工学部の土屋喜一教授, 東京女 第 49 巻 第 8 号 
子医大の三浦茂教授並びに東芝総合研究所の案野剛輔, 横山能周博士等に感謝します。尚本研究の一部は文 部省科学研究費補助金研究課題「757187」と厚生省癌研究助成課題「䄉毛がんの原因とその適正取扱いに関 する研究」の補助金の援助によった。

文献

1）東條伸平, 望月真人, 新谷 毅, 金沢精一, 坂井孝至 : 日産婦誌, $22: 662(1970)$.

2) 東條伸 平：産婦人科治療, $24: 535(1972)$ ～3) Tojo, S., Tsuchiya, K., Miura, S., Anno, G., Mochizuki, M., Niiya, T., Kanazawa, S. and Sakai, T. : Acta Obst. \& Gynec. Japonica 17 : 263 (1970).

4) Tojo, S., Sakai, T., Kanazawa, S. and Mochizuki, M. : VII World Congress on Fertility and Sterility Invited Lectures/symposia paper. Excerpta Medica, Tokyo, p. 153 (1971). 5) Tojo, S., Sakai, T., Kanazawa, S. and Mochizuki, M. : Acta Obst. Gynec. Scand. 51 : 265 (1972).

6) Hans-Jurgen Hohorst : Method of Enzymatic Analysis. p. 266, Ed. H.U. Bergmeyer, Acad. Press, N.Y. (1965). 7) Shibata, S. : The Technique of Glinical Examination. p. 214, Kanehara, Tokyo (1960). $\quad$ 8) A.L. Bobson, G.E. Philips : Clinical Ghemica. Acta Vol 12. (1965) p. 210 9) Midgley, A.R. and Jaffe, R.B : J. Clin. Endocrinol. $26: 1375$ (1966). 10) Greenwood, F.G. and Hunter, W.M. : Biochem. J. 89 : 114 (1963). 11) Johanson, E.D.B. : Acta Endocr. (kbh) $61: 592$ (1969). 12) Matsuzawa, D. : Autorodiograph. Asakura Shoten, Tokyo (1969). 13) Belzer, F.O., Ashby, B.S., May, R.E. and Dunphy, J.E. : Organ Perfusion and Preservation. Ed. J.C. Norman. p. 7. Appleton Century Crofts, N.Y. (1968).

72 DK 2400. Gopenhagen Nv. Denmark.

14) Astrup : 装置 : Radiometer A/S Embrupvej K., Tsuchihashi, T., Shimura, T. : Am. J. Obstet, Gyn. (1973, in press) 